\title{
How will future health policy impact on regional disparities and healthcare in Latvia
}

\author{
Ieva Bikava $^{1}$ and Ilga Kreituse $^{2}$ \\ ${ }^{1}$ Rīga Stradiņš University, Riga, Latvia \\ ${ }^{2}$ Rịga Stradiņš University, Department of Political Science, Riga, Latvia
}

\begin{abstract}
Latvia is a country with high level of regional disparities and as researches have approved - income, education, and environment significantly affect the status of people's health.

The reforms in healthcare have been carried out under the flags of accessibility, efficiency, effectiveness, and quality since 1991. Some groups support the idea that the state should take over almost all services, the others claim that more responsibilities should be transferred to the private sector, and dispute on service provider network and financing system.

In accordance with the coalition theory and legislation of Latvia, the initiators and designers of the structural reforms are politicians, elected by the citizens. In theory, every politician represents the political party with its ideology and vision that is expressed in the Programme of the party.

Due to Parliament elections in 2018 , to understand which way the country will go, and how the chosen strategy will impact on the regional disparities, analysis of the middle-term development strategy was made.

Research results showed that political parties in Latvia are not based on the ideology and the strategical development vision of the State, so the development and changes made in legislation are mainly ad-hoc decisions or the result of lobbying activities of influential groups.

Due to the lack of middle term vision as the gap between long-term development strategy and short-term decisions, unfortunately, the prognosis of future health politics leads to the conclusion that regional disparities and the problem with Health care accessibility in next decades will only rise.
\end{abstract}

Key words: health policy, regional disparities, political party ideology.

\section{Introduction}

Due to coming Parliamentary elections in October 2018 new political parties were established, with different visions and solutions how the state should develop, based on diverse ideological roots, but all with the same aims - to work on better policies, to raise the prosperity, to make the state become more effective and efficient.

The Health policy issues were on every party's agenda - to provide health care accessibility to inhabitants, through different ways - some by promoting more money to battle the quotas, others - to provide better salaries to medical specialists, others to work on cheaper medications.

According to medium-term policy planning the document "Public Health Guidelines 2014-2020" - "the overarching objective of public health policy is to increase the number of healthy years of inhabitants of Latvia and to prevent premature death, preserving, improving and restoring health". For this purpose, one of the sub-objectives is "to prevent inequality in healthcare by taking measures for ensuring equal health promotion and health care opportunities for inhabitants of Latvia". The other objective is "to ensure efficient 
Table 1. Average monthly wages and salaries by statistical region (in euro) [4].

\begin{tabular}{|l|c|c|c|c|c|}
\hline Region/Year & $\mathbf{2 0 1 3}$ & $\mathbf{2 0 1 4}$ & $\mathbf{2 0 1 5}$ & $\mathbf{2 0 1 6}$ & $\mathbf{2 0 1 7}$ \\
\hline Riga region & 583 & 633 & 679 & 710 & 758 \\
\hline Vidzeme region & 410 & 444 & 480 & 502 & 544 \\
\hline Kurzeme region & 441 & 479 & 512 & 529 & 568 \\
\hline Zemgale region & 436 & 476 & 509 & 539 & 579 \\
\hline Latgale region & 358 & 388 & 419 & 440 & 471 \\
\hline Latgale: Riga & $61.41 \%$ & $61.30 \%$ & $61.71 \%$ & $61.97 \%$ & $62.14 \%$ \\
\hline
\end{tabular}

Table 2. Unemployment rate by statistical region in age group 15-64 (\%) [5].

\begin{tabular}{|l|c|c|c|c|c|}
\hline Region/Year & $\mathbf{2 0 1 3}$ & $\mathbf{2 0 1 4}$ & $\mathbf{2 0 1 5}$ & $\mathbf{2 0 1 6}$ & $\mathbf{2 0 1 7}$ \\
\hline Riga region & 10.8 & 8.3 & 7.5 & 7.8 & 7.9 \\
\hline Vidzeme region & 13.4 & 13.3 & 11.8 & 9.4 & 9.8 \\
\hline Kurzeme region & 10.4 & 13.0 & 10.8 & 10.1 & 9.0 \\
\hline Zemgale region & 15.4 & 13.0 & 11.5 & 12.3 & 9.5 \\
\hline Latgale region & 17.3 & 17.3 & 19.0 & 17.9 & 14.4 \\
\hline
\end{tabular}

management of the health care system and rational utilisation of resources in order to improve the sustainability of operation of the health care system and equal access for all inhabitants of Latvia to good quality health care services, which are funded from the State budget resources" [1].

To improve public health means not only actions on clinical health care issues, but also "interventions with actions on equity and social determinants of health and necessary key health system inputs, such as human resources and medicines". Countless researches have indicated that there is a direct impact of social determinants on health outcomes in an individual as well as the whole society. "Health inequalities arise from the societal conditions in which people were born, grow, live, work and age referred to as social determinants of health" [2].

Income inequality during the last decade has dropped from 37.5 in 2008 to 34.5 in 2017, but is still very high, in 2017 being the third largest value in European Union, just after Bulgaria (40.2) and Lithuania (37.6) [3]

In Latvia's case, income inequality has regional features with significant difference comparing the centre - Riga with the rural areas, especially the Latgale region as represented in Table 1.

The regional difference in average monthly income comparing the centre - Riga and Latgale - the region that is on the European Union border with Russia, differs significantly in a long period, and the average salary in Latgale is only $2 / 3$ of average income in Riga.

There is not only difference in income level, but also different possibilities to get work, which means difference in unemployment rate, as represented in Table 2.

According to data on the unemployment for five-year period, the rate of unemployment in Latgale is twice higher than in Riga. Both of these conditions - higher unemployment rate and lower salaries lead to higher poverty rate which also has dramatic regional differences as represented in Table 3. 
Table 3. Share of persons under minimum income level by statistical regions (\%) [6].

\begin{tabular}{|l|c|c|c|c|c|}
\hline Region/Year & $\mathbf{2 0 1 2}$ & $\mathbf{2 0 1 3}$ & $\mathbf{2 0 1 4}$ & $\mathbf{2 0 1 5}$ & $\mathbf{2 0 1 6}$ \\
\hline Riga region & 3.5 & 4.1 & 3.6 & 3.4 & 3.7 \\
\hline Vidzeme region & 14.4 & 13.4 & 13.1 & 9.5 & 10.9 \\
\hline Kurzeme region & 8.0 & 8.3 & 8.0 & 7.4 & 8.0 \\
\hline Zemgale region & 10.1 & 10.3 & 12.7 & 7.8 & 9.7 \\
\hline Latgale region & 15.1 & 14.5 & 18.6 & 17.1 & 16.1 \\
\hline
\end{tabular}

Table 4. Reasons for unmet needs for medical care for persons 16 or over (\%) [7].

\begin{tabular}{|l|c|c|c|c|c|c|}
\hline Reason & \multicolumn{2}{|c|}{$\begin{array}{c}\text { Could not afford to } \\
\text { (too expensive) }\end{array}$} & \multicolumn{2}{|c|}{$\begin{array}{c}\text { Wanted to wait and } \\
\text { see if problem got } \\
\text { better on its own }\end{array}$} & \multicolumn{2}{|c|}{$\begin{array}{c}\text { Too far to travel/ } \\
\text { no means of } \\
\text { transportation }\end{array}$} \\
\hline Year & Urban & Rural & Urban & Rural & Urban & Rural \\
\hline 2013 & 60.9 & 58.1 & 13.7 & 21.5 & 1.8 & 4.4 \\
\hline 2014 & 53.7 & 56.1 & 15.1 & 27.1 & 1.7 & 3.6 \\
\hline 2015 & 57.2 & 59.1 & 14.5 & 18.4 & 2.2 & 4.2 \\
\hline 2016 & 41.7 & 51.2 & 16.4 & 20.9 & 2.9 & 6.1 \\
\hline 2017 & 42.5 & 44.6 & 21.6 & 25.4 & 3.3 & 6.6 \\
\hline
\end{tabular}

In the circumstances of twice higher unemployment rate and significantly lower average income level, the share of the poverty rate in Latgale region is five times higher than in Riga. As known from several researches, the higher poverty rate leads to worse health outcomes as one of the most influential social determinants. Those data leads to the conclusion, that health status of Latgale region inhabitants is significantly worse than in Riga.

In addition to worse health conditions, affected by social determinants, the availability of health care services is also more restricted in the rural region due to the lack of human resources - availability of medical doctors and nurses. The analyses of unmet needs in urban and rural regions by the leading causes are shown in Table 4 .

Analysis of reasons for unmet needs indicates that leading obstacle is high costs for both urban and rural inhabitants. In the course of time, the main cause "too expensive" is getting lower, but other worrying trend arises - the share of people who postpone the medical care rises significantly, that can be explained also with financial issues. Too far to travel is not one of the leading obstacles, but at the same time is twice higher for rural than urban population. However all indicators show that the level of unmet needs is higher for rural than urban population.

Summarizing the above mentioned - there are significant regional disparities in health status and health care availability in Latvia, that are based on social determinants and disparities in medical service availability in regions.

\section{Political parties as the agents of change}

According to the political theory, the initiators of structural reforms are politicians, elected in Parliament and Government. In accordance with the Constitution of Latvia - the members of the Parliament are elected from political parties, which participate in elections. The parties 
that get more than 5\% of votes get places in Parliament and take part in forming the Coalition. The Coalition forms the Government by nominating the candidates of the Ministers and prepares the Government Declaration - the document, that contains main aims and tasks that Government undertakes to achieve during their governance term. The Cabinet of Ministers and the Government Declaration afterwards are affirmed by the vote of Parliament, if the majority of parliament members vote for.

Thereby, the idea of changes or reforms raises in the political party that is elected in the Parliament and presented through the elected deputy. The theories on political parties, political power and formation of the coalition emphasize that every politician is motivated to be elected for the next term, so they are concerned about the voters' confidence, trust and loyalty. To gain and enhance the trust of the voters, every politician tries to fulfil the promises that were given to voters.

In multiple political party systems, which is the case of Latvia, the competition is among the political parties, which are represented by the members of parties, who are nominated as the candidates for deputy. Every political party is presented not only by the people but also by the pre-election Programme that contains the main party commitments to society.

In political theory, "the parties ensure that the citizens are permanently capable to act politically. They articulate and integrate different interests, visions and opinions. They are also the main source for the recruitment of political elites. In order to participate successfully in elections, the political parties have to be the voice of broad sectors of society" [8].

Thereby, political parties that not only participate in elections, but also are elected, should present the voice of majority of society and embody the will of the nation, they should be the persons who understand the needs and problems to be solved and have ideas and visions that are acceptable by their voters.

All political parties have some kind of core values that consolidate all the members and distinct one party from another. For example, in the USA, there are two main political divisions - Republicans and Democrats. Depending on which party get the majority or win the elections, it can be predicted what will be the main values on which the further development of the state will be based on. Will it serve more to interests of the capital and free market - if the winning party is Republicans, or will it be towards the welfare of the state - if the lead is taken by Democrats.

According to Political theory, there are several courses of ideologies - Liberalism, Conservatism, Socialism, Nationalism, as well as others more specific, like Christian Democrats, Pacifism, Ecology, etc.

In classic politics, ideology is the determining factor, based on which every party declares their main values and vision of the state development. In contemporary politics, the role of ideology has diminished and blurred, and nowadays it is not the main identity factor for the political party. Furthermore, there even are parties, which are based on opposite ideologies - they are liberal on human rights issues, but are conservative in economic development issues.

Nevertheless, the ideology is one of the most significant factors that indicate the core values of the party, their vision of society and social developments. In accordance with Coalition building theories, political parties form alliances and associations, based on a common ideological platform. The alliances of parties are established by unifying values and goals, even if they are not quite similar in their vision of the state development and in some issues can even be of the opposite point of view. However, the question is - can these disagreements be put aside to reach more important unifying goals [9]?

The main document of party's vision, mission, and tasks to achieve is the programme. "Party programme constitutes the identity of the party and offers the general orientation to the citizens and voters on the guiding principles and ideas of a party. With its programme 


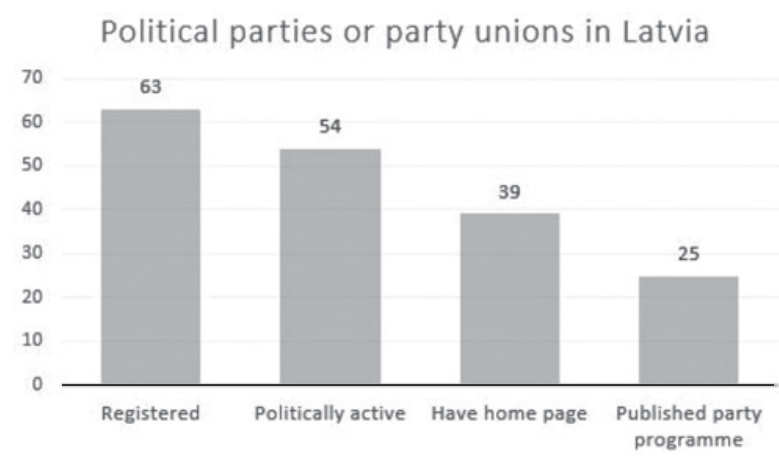

Fig. 1. Characteristics of political parties or party unions in Latvia.

the party justifies its existence and explains how it differentiates itself from others. The party programme illustrates political ambition and basic values, demands and suggestions for a party" [8].

Significant is not only political party's programme, but also the requirement to register a political party in Latvia. The Law of Political parties in Latvia states that political party is the organization that is established in order to take political activities, participate in election campaigns, nominate deputy candidates, and through elected deputies realize political party programme [10].

Considering the Constitution of Latvia, the Law of Political Parties in Latvia, as well as attainments of political theory, the research of political parties' programmes that are campaigning for the participation in the government should be carried out in order to understand the development of future policy and its main values.

\section{The vision of the future in the political parties' programmes}

To understand the vision of the future state according to political parties that are competing for the governance, the research of the programmes of the active political parties in Latvia was conducted.

All political parties are registered in Enterprise Register of Latvia. According to data from the Register, before the $13^{\text {th }}$ Parliament elections, there were 51 political party and 10 political party unions in Latvia, that can be considered as active (party or party unity that is registered and there is no information about liquidation process) [11].

Considering the fact that not all of the registered parties or party unions are politically active, four factors were taken into account to identify whether a political party or party union can be considered as politically active: 1) political party or a union of political parties have participated in the previous, $12^{\text {th }}$ Parliament, elections; 2 ) whether the party participated in municipal elections in 2017; 3) whether it has submitted Annual Report of the year 2017 to KNAB; 4) was it registered in 2018 [12, 13]. According to these criteria - 54 or $88.5 \%$ of parties and party unions can be considered as politically active.

Nowadays the main sources of information are web and social networks thereby assumption was made that every active political party should be on the Internet, that means to have the home page. The research indicated that only 39 or $72 \%$ of active political parties or party unions have their home page. The further research of the content of the party or party union home page led to results that only 25 or $46 \%$ of active parties or party unions have published their programme on the web page (Fig. 1). 


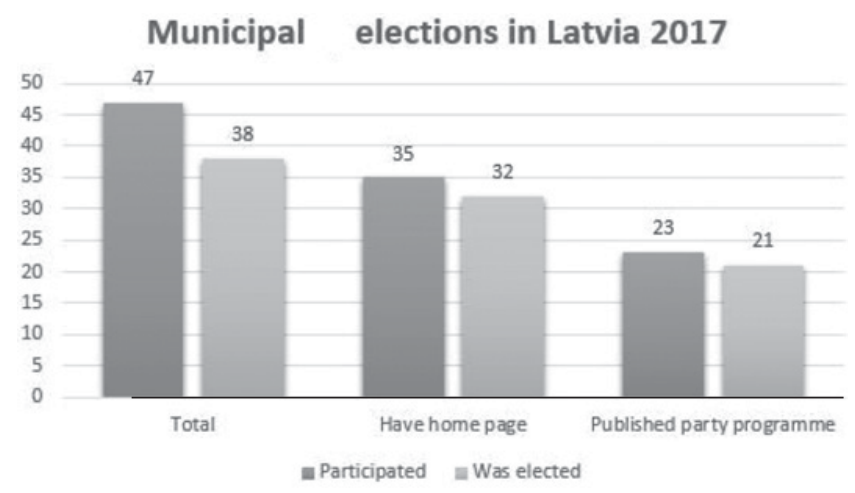

Fig. 2. Political parties or party unions in Municipal elections in Latvia, 2017.

Despite the fact that the programme of the political party is a compulsory document that has to be submitted to Enterprise registry to register the political party, the programme is not the document that can be easily found. Even of the parties that have their web page, only a few have published their programme.

These findings indicate that the party programme, the document that according to political theory - justifies the party's existence and explains how it differentiates itself from others, is not meaningful in Latvia. Even more, we can say that the development of party programme as the document that has to be submitted to Enterprise registry to register the political party, for a significant share of parties is done formally, not meaningfully.

To understand voter's expectations and the requirement for the existence of party programme, the further research was carried out analyzing political parties which participated and were elected in municipal elections in 2017.

According to the data from the Central Election Commission of Latvia, in Local elections in 2017, 47 political parties and party unions participated. Exploring their websites, we found out that 35 of participating parties or party unions had their web pages, and 23 of them had published their programme. The parties or party unions that had been elected in at least one municipality - were 38, of them 32 had a web page and 21 had published their programme on their web page (Fig. 2).

The results, comparing participated and elected parties or party unions, showed that publicly available party programme is not a significant factor for the voters, because there were elected $17(45 \%)$ parties or party unions, which had not published their programme and $6(16 \%)$ of them even did not have their web page.

This phenomenon can be explained by the local character of the elections. The local voters are familiar with members of local parties, and before elections, every political party organizes local events and activities to introduce and attract potential local voters.

Especially in local scale elections, direct mail, posters, and handouts are the tactics that are used to attract the voters.

To gain a deeper understanding of the value of the party programme for a potential voter, analysis of the political parties and unions that took part in the previous $12^{\text {th }}$ Parliament elections was made.

According to the data from the Central Election Commission of Latvia, in the $12^{\text {th }}$ Parliament election in 201412 political parties and party unions participated. Exploring their websites, we found out that 11 of participating parties or party unions had their web pages, and 7 of them had published their programme on the web page. 
12th Parliament elections in Latvia, 2014

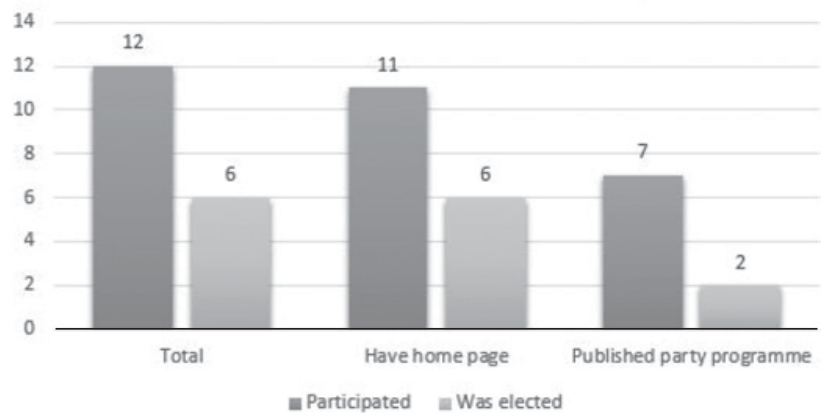

Fig. 3. Political parties or party unions in $12^{\text {th }}$ Parliament elections in Latvia, 2014.

The results, comparing participated and elected parties or party unions, showed that publicly available party programme is not a significant factor for the voters in both municipal and in Parliament elections, since there were 6 parties or party unions elected, all of them had web pages, but only 2 of them had published their programme on web page.

According to results, in Latvia, the political party programme is the significant factor neither for political parties nor for the voters. With reference to political theory, programme is the document that deals with the ideology of the party, their vision, and mission. The research reveals that ideology is not the backbone of the political party in Latvia.

As there is not the possibility to predict the future of the state basing on theoretical approach - on the ideology and the programme, analysis of pre-election programmes available on the Central Election Commission of Latvia home page was made in order to find out what promises political parties offer to voters.

Since the problem issue for research was regional inequalities, the context analysis of all 16 party pre-election programmes was made to search issues on inequality or regional development.

Although inequality and regional disparities are the issues that are on the agenda for a long time, only 11 of 16 political parties or party unions have mentioned the terms "regional policy" or "regional development". Taking a closer look at the content, only 7 of 16 programmes identified the need to work on regional disparities in the Healthcare sector in their programmes.

From those 16 parties and party unions that participated in elections - seven were elected. Work on regional development was mentioned in 4 party or party union programmes and only 3 of them had on their agenda goal to achieve better health care accessibility for every inhabitant in all regions. From those 7 elected parties or party unions, only one with 13 mandates of 100 Parliament members had declared that they would assess the impact of every decision on inequality and would not support the reforms that increase the inequality.

\section{Conclusions}

Results of research on political party programmes indicated that political parties in Latvia are not formed on ideology bases, and since there is the lack of party programmes, parties do not have vision of strategic development of the State.

As the results of elections showed - a significant part of Citizens made their choice in elections basing on other factors, not on the programme and ideology of the political party. 
So, the political party programme and ideology is a significant factor neither for political parties, nor voters.

That can lead to the rise of populism in society, but in the legislative process can lead to the situation that state development and changes in the legislature are mainly ad-hoc decisions or the result of lobbying activities.

The lack of middle-term objectives and goals is threatening the possibilities to attain long-term state development plans and can deepen the problem of regional disparities and inequality.

Evaluation of the election results of the $13^{\text {th }}$ Parliament elections in Latvia in 2018 indicates that most of the elected parties are "right-wing parties" as they describe themselves - that means that they are mostly based on liberal or conservative ideology. As the research of pre-election programmes indicated - the work on regional disparities and inequality is not a priority for the majority of the Parliament.

Due to the lack of middle term vision as a gap between long-term state development strategy and short-term strategy, there is no road map of activities to achieve those long- term vision and goals.

Unfortunately, the prognosis, based on the research results, is that regional disparities and healthcare accessibility problems for rural areas will rise.

\section{References}

[1] Cabinet of Ministers, Cabinet Order No. 589 of 14 October, 2014. Public Health Policy Guidelines 2014-2020. Available at: https : //likumi .1v/ta/en/en/ id/269591-on-the-public-health-policy-guidelines-2014-2020 [viewed 27.01.2019]

[2] World Health Organization Regional Office for Europe, Health 2020. A European policy framework and strategy for the 21 st century. Available at: http://www. euro.who.int/__data/assets/pdf_file/0011/199532/Health2020-Long. pdf?ua=1 [viewed 27.01.2019]

[3] Eurostat, Gini coefficient of equivalised disposable income - EU-SILC survey. Last updated 19-01-2019. Available at: http://appsso.eurostat.ec.europa.eu/ nui/submit ViewTable-Action.do [viewed 27.01.2019]

[4] Central Statistic Bureau of Latvia, Social Processes. Wage and Salaries. Annual Data. DSG050. Average monthly wages and salaries by statistical region (in euro). Latest update 3/1/2018 [viewed 29.01.2019]

[5] Central Statistic Bureau of Latvia, Social Processes. Employement and Unemployement. Economic Activity. Annual data. NBG040. Activity rate, employement rate and unemployememt rate by statistical region (\%). Latest update 2/22/2018 [viewed 29.01.2019]

[6] Central Statistic Bureau of Latvia, Social Processes. Poverty and Inequality (EUSILC). Minimum income level. MIG020. Share of persons under minimum income level by statistical regions of Latvia (\%). Latest update 3/2/2018 [viewed 29.01.2019]

[7] Central Statistic Bureau of Latvia, Social Processes. Health. Self-perceived Health Status (EU-SILC). VPG072. Reasons for unmet need for medical care (except dental) for persons aged 16 or over (\%). Latest update 1/17/2019 [viewed 29.01.2019]

[8] W. Hofmeister, K. Grabow, Political Parties. Functions and Organisation in Democratic Societies (Konrad Adenauer Stiftung, 2011)

[9] H. Noel, Political Parties and Ideology. Interest Groups in Context. New Directions in Interest Group Politics (Routledge, 2014) 
[10] Saeima, Politisko partiju likums. No 01.05.2017. Available at: https://likumi.lv/ ta/id/139367-politisko-partiju-likums [viewed 30.01.2019]

[11] Uzņēmumu reǵistrs, Politisko partiju un to apvienību saraksts. Available at: https://www.ur.gov.lv/lv/registre/organizaciju/politiska-partija/ politisko-partiju-un-to-apvienibu-saraksts/?filter=ppa\&search= [viewed 30.01.2019]

[12] Centrālā Vēlēšanu komisija, Vēlēšanas. Available at: https://www.cvk.lv/lv/ velesanas/saeimas-velesanas [viewed 30.01.2019]

[13] Korupcijas novēršanas un apkarošanas birojs, Partiju Finanšu datu bāze. Partiju deklarācijas. Available at: https://www.knab.gov.lv/lv/db/declaration/ [viewed 30.01.2019] 